Int. J. Electrochem. Sci., 15 (2020) 3761 - 3775

International Journal of

ELECTROCHEMICAL

SCIENCE

WWW.electrochemsci.org

\title{
Electrochemical Activity of Thin-Film Pd Catalysts Modified with Bi for Methanol and Ethanol Oxidation Reaction in Alkaline Solution
}

\author{
Jelena D. Lović*, Sanja I. Stevanović \\ ICTM Department of Electrochemistry, University of Belgrade, Njegoševa 12, 11001 Belgrade, Serbia \\ "E-mail: jelena.lovic@ihtm.bg.ac.rs, jlovic@tmf.bg.ac.rs
}

doi: $10.20964 / 2020.05 .14$

Received: 6 January 2020 / Accepted: 2 March 2020 / Published: 10 April 2020

\begin{abstract}
Thin-film Pd catalysts with low metal loadings (55 and $110 \mu \mathrm{g} \mathrm{cm}^{-2}$ ) were obtained by electrodeposition from a surfactant-free green electrolyte on glassy carbon (GC) electrode. Pd/GC catalysts were modified by addition of various amounts of $\mathrm{Bi}$ via irreversible adsorption. The catalysts were characterized by atomic force microscopy (AFM) and then studied in methanol oxidation reaction (MOR) and ethanol oxidation reaction (EOR) in alkaline solution. Electrochemical tests shown that the modification of the appropriate amount of $\mathrm{Bi}$ on $\mathrm{Pd} / \mathrm{GC}$ catalyst enhance activity toward MOR and EOR up to about 2-3 times compared to unmodified catalysts. Besides surface Bi coverage $\left(\Theta_{\mathrm{Bi}}\right)$ of 0.6 increase durability and provides more poisoning tolerant $\mathrm{Pd} / \mathrm{GC}$ electrode in both studied reactions. The improvement of electrochemical performances of $\mathrm{Bi}$ modified $\mathrm{Pd} / \mathrm{GC}$ catalysts is attributed to the third body effect and the bifunctional mechanism.
\end{abstract}

Keywords: Electrodeposition; Palladium; Bismuth adsorption; Alcohol oxidation; Atomic force microscopy.

\section{$\underline{\text { FULL TEXT }}$}

(C) 2020 The Authors. Published by ESG (www.electrochemsci.org). This article is an open access article distributed under the terms and conditions of the Creative Commons Attribution license (http://creativecommons.org/licenses/by/4.0/). 